\title{
Effect of Foliar Application of Acetyl Salicylic Acid and Ascorbic Acid on Flowering, Pickings and Yield of Garden Pea
} (Pisum sativum L.) cv. Bonneville

\author{
T. Thomson*, G.S. Patel, J.B. Thakar and K.S. Pandya \\ Department of Vegetable Science, College of Horticulture, SD Agricultural University, \\ Sardarkrushinagar - 385506, Gujarat, India \\ *Corresponding author
}

A B S T R A C T

Keywords

Acetyl Salicylic Acid, Ascorbic

Acid, Garden pea,

Flowering,

Pickings.

Article Info

Accepted:

23 May 2017

Available Online:

10 June 2017
A field study was conducted at Horticulture Instructional Farm, CP College of Agriculture, SD Agricultural University, Sardarkrushi nagar, Gujarat to find out the effect of foliar application of acetyl salicylic acid and ascorbic acid on growth and yield of garden pea (Pisum sativum L.) cv. Bonneville. Plants were sprayed with treatments viz. control, NAA (25 and $50 \mathrm{ppm})$, $\mathrm{GA}_{3}$ (50 and $100 \mathrm{ppm}$ ), 2, 4-D (5 and $10 \mathrm{ppm}$ ), acetyl salicylic acid (100 ppm and $200 \mathrm{ppm}$ ), ascorbic acid (100 and $200 \mathrm{ppm}$ ) at 30 days after sowing. The results revealed that the antioxidant acetyl salicylic acid 200 ppm effective for minimum days taken for flowering whereas ascorbic acid $200 \mathrm{ppm}$ has given best results for total number of pickings, minimum days taken for first picking, minimum days taken for last picking, yield per plot and yield per hectare.

\section{Introduction}

Amongst pulse crops, Pea (Pisum sativum L.) is a popular pulse crop with vernacular name 'Matar'. It belongs to the family Leguminoceae. It is second important food legume of the world. Pea is native of South West Asia and is widely grown in temperate countries. India is a thickly populated country and most of the residents of this country are vegetarian. The population being increased without check is the main handicap in our progress, with the results of that food shortage, malnutrition and poverty occurs. The solution for control of these problems partly may be only the major source of adoption of intensive cultivation of vegetable crops. Several kinds of vegetables are grown in India, out of them vegetable pea is one of the most important leguminous vegetable, having much more protein than others vegetables. Pea is highly nutritive containing high percentage of digestible protein along with carbohydrates (15.8 g), Vitamin A (139 I.U.), Vitamin C (9 mg), magnesium (34 mg) and phosphorus (139 mg) per $100 \mathrm{~g}$ of edible portion.

To see the malnutrition and protein deficient diet and low yield of pea, it is necessary to 
increase pea production per unit area to meet the requirement of increasing population of our nation. Besides, good agronomic practices like growing high yielding varieties, providing proper spacing, irrigation, use of fertilizers, optimum sowing time and some advanced crop improvement techniques like application of antioxidants and appropriate plant protection measures ought to be essentially followed in order to increase the productivity. Increasing the production of peas green pods and dry seeds with high quality could be achieved through using the foliar application of antioxidants, i.e. Ascorbic Acid (AA), Salicylic Acid (SA). Ascorbic acid as an abundant component of plants functions as an antioxidant and an enzyme cofactor. It participates in a variety of processes including photosynthesis, cell wall growth and cell expansion, resistance to environmental stresses and synthesis of ethylene, gibberellins, anthocyanine and hydroxyl proline. SA is assigned diverse regulatory roles in the metabolism of plants. SA has direct involvement in plant growth, thermogenesis, flower induction and uptake of ions. It affects ethylene biosynthesis, stomatal movement and also reverses the effects of ABA on leaf abscission. Enhancement of the level of chlorophyll, photosynthetic rate and modifying the activity of some of the important enzymes are other roles assigned to $\mathrm{SA}$.

\section{Materials and Methods}

The present investigation were executed at Horticulture Instructional Farm, CP College of Agriculture, Sardarkrushinagar Dantiwada Agricultural University, Sardarkrushinagar, Gujarat during the year 2013 with eleven treatments viz. NAA (25 and $50 \mathrm{ppm}), \mathrm{GA}_{3}$ (50 and $100 \mathrm{ppm}), 2,4-\mathrm{D}$ (5 and $10 \mathrm{ppm}$ ) and antioxidants acetyl salicylic acid (100 and 200 ppm) and ascorbic acid (100 and 200 ppm) along with control (water) sprayed after 30 days after sowing of pea variety Bonneville.
The experiment was laid out in a randomized block design with four replications. To raise the crop recommended package of practices was followed. The crop was sown in November 2013 during Rabi season. The effect of different treatments was studied and data recorded on flowering, pickings and yield of the crop on ten randomly selected plants. The mean data were subjected to statistical analysis following analysis of variance technique (Nigam and Gupta 1979).

\section{Results and Discussion}

\section{Days taken for flowering}

Among the various concentrations of the ascorbic acid and acetyl salicylic acid studied minimum days taken for flowering (51.35 days) was recorded with the treatment applications of acetyl salicylic acid 200 ppm. Maximum days taken for flowering were recorded with the treatment application of control. The results have been given in the table 1

Similar results were also reported by Tarchevsky et al., (2011) in pea, Tomader and Rahman (2005) in cowpea, Akram (2007) in broad bean, Amal and Amira (2007) in common bean, Amal and Amira (2009) in pea.

\section{Total number of pickings}

Maximum total number of pickings (3.50) was recorded with the treatment application of ascorbic acid $200 \mathrm{ppm}$ and was found to be superior over acetyl salicylic acid concentrations. Minimum total number of pickings was recorded with the treatment application of control. The results have been given in the table 1. Similar results were also reported by Akram (2007) in broad bean, Amal and Amira (2007) in common bean, Amal and Amira (2009) in pea, Tomader and Rahman (2005) in cowpea. 


\section{Days taken for first picking}

Minimum days taken for first picking (92.00 days) was recorded with the treatment application of ascorbic acid $200 \mathrm{ppm}$ and was found to be superior over acetyl salicylic acid concentrations. Maximum days taken for first picking were recorded with the treatment application of control. The results have been given in the table 2. Similar results were also reported by Akram (2007) in broad bean, Amal and Amira (2007) in common bean,
Amal and Amira (2009) in pea.

\section{Days taken for last picking}

Minimum days taken for last picking (115.75 days) was recorded with the treatment application of ascorbic acid $200 \mathrm{ppm}$ and was found to be superior over acetyl salicylic acid concentrations. Maximum days taken for last picking were recorded with the treatment application of control. The results have been given in the table 2.

Table.1 Effect of foliar application of acetyl salicylic acid and ascorbic acid on days taken for flowering and total number of pickings of garden pea (Pisum sativum L.) cv.

Bonneville at 30, 45 and 60 DAS

\begin{tabular}{|c|c|c|}
\hline Treatments & Days taken for Flowering & Total Number of pickings \\
\hline Control & 52.75 & 2.50 \\
\hline NAA 25 ppm & 52.27 & 2.75 \\
\hline NAA 50 ppm & 51.92 & 3.25 \\
\hline $\mathrm{GA}_{3} 50 \mathrm{ppm}$ & 49.62 & 3.00 \\
\hline $\mathrm{GA}_{3} 100 \mathrm{ppm}$ & 48.97 & 3.25 \\
\hline $2,4-\mathrm{D} 5 \mathrm{ppm}$ & 50.75 & 3.25 \\
\hline 2,4-D 10 ppm & 51.62 & 3.00 \\
\hline Acetyl Salicylic acid 100 ppm & 51.47 & 2.75 \\
\hline Acetyl Salicylic acid 200 ppm & 51.35 & 3.00 \\
\hline Ascorbic acid 100 ppm & 52.42 & 3.25 \\
\hline Ascorbic acid 200 ppm & 51.55 & 3.50 \\
\hline S.Em. \pm & 1.04 & 0.10 \\
\hline CD at 5\% & 3.02 & NS \\
\hline
\end{tabular}

Table.2 Effect of foliar application of Acetyl Salicylic Acid and Ascorbic Acid on days taken for first picking and days taken for last picking of garden pea (Pisum sativum L.) cv.

Bonneville at 30 days and last harvesting

\begin{tabular}{|c|c|c|}
\hline Treatments & Days taken for First Picking & Days taken for Last Picking \\
\hline Control & 105.50 & 119.00 \\
\hline NAA 25 ppm & 101.75 & 117.75 \\
\hline NAA 50 ppm & 100.25 & 116.75 \\
\hline $\mathrm{GA}_{3} 50 \mathrm{ppm}$ & 98.00 & 117.50 \\
\hline $\mathrm{GA}_{3} 100 \mathrm{ppm}$ & 97.00 & 117.50 \\
\hline $2,4-\mathrm{D} 5 \mathrm{ppm}$ & 95.50 & 117.50 \\
\hline $2,4-\mathrm{D} 10 \mathrm{ppm}$ & 101.75 & 117.50 \\
\hline Acetyl Salicylic acid 100 ppm & 102.75 & 118.75 \\
\hline Acetyl Salicylic acid 200 ppm & 100.75 & 117.50 \\
\hline Ascorbic acid 100 ppm & 101.50 & 116.75 \\
\hline Ascorbic acid 200 ppm & 92.00 & 115.75 \\
\hline S.Em. \pm & 1.90 & 1.95 \\
\hline CD at 5 \% & NS & NS \\
\hline
\end{tabular}


Table.3 Effect of foliar application of Acetyl Salicylic Acid and Ascorbic Acid on yield per plot and yield per hectare of garden pea (Pisum sativum L.) cv. Bonneville

\begin{tabular}{|c|c|c|}
\hline Treatments & Yield / Plot $(\mathbf{k g})$ & Yield / Hectare (q) \\
\hline Control & 1.715 & 73.29 \\
\hline NAA 25 ppm & 1.855 & 79.27 \\
\hline NAA 50 ppm & 1.865 & 79.70 \\
\hline GA $_{3} 50 \mathrm{ppm}$ & 2.031 & 86.79 \\
\hline $\mathrm{GA}_{3} 100 \mathrm{ppm}$ & 2.094 & 89.48 \\
\hline 2,4-D 5 ppm & 2.668 & 114.01 \\
\hline 2,4-D 10 ppm & 1.922 & 82.13 \\
\hline Acetyl Salicylic acid 100 ppm & 1.918 & 81.96 \\
\hline Acetyl Salicylic acid 200 ppm & 1.971 & 84.23 \\
\hline Ascorbic acid 100 ppm & 1.982 & 84.70 \\
\hline Ascorbic acid 200 ppm & 2.024 & 86.49 \\
\hline S.Em. \pm & 0.06 & 2.82 \\
\hline CD at $\%$ & 0.19 & 8.17 \\
\hline
\end{tabular}

Similar results were also reported by Akram (2007) in broad bean, Amal and Amira (2007) in common bean, Amal and Amira (2009) in pea.

\section{Yield / Plot (kg)}

Maximum yield per plot $(2.024 \mathrm{~kg})$ was recorded with the treatment application of ascorbic acid $200 \mathrm{ppm}$ and was found to be superior over acetyl salicylic acid concentrations. Minimum yield per plot was recorded with the treatment application of control. The results have been given in the table 3 .

Similar results were also reported by Akram (2007) in broad bean, Amal and Amira (2007) in common bean, Amal and Amira (2009) in pea. Anitha et al., (1999) in pea, Azooz et al., (2011) in broad bean, Nour et al., (2012) in broad bean.

\section{Yield / Hectare (q)}

Maximum yield per hectare (86.49 q) was recorded with the treatment application of ascorbic acid $200 \mathrm{ppm}$ and was found to be superior over acetyl salicylic acid concentrations. Minimum yield per plot was recorded with the treatment application of control. The results have been given in the table 3 .

Similar results were also reported by Akram (2007) in broad bean, Amal and Amira (2007) in common bean, Amal and Amira (2009) in pea. Anitha et al., (1999) in pea, Azooz et al., (2011) in broad bean, Nour et al., (2012) in broad bean.

From the investigations it can be concluded that the antioxidant acetyl salicylic acid 200 ppm effective for minimum days taken for flowering whereas ascorbic acid 200 ppm has given best results for total number of pickings, minimum days taken for first picking, minimum days taken for last picking, yield per plot and yield per hectare.

\section{References}

Akram, A. A. (2007). Protection of broad beans in KSA against adverse effects of ambient ozone using ascorbic acid on growth and yield characteristics. 
Proceeding of the second scientific environmental conffer, Zagazig Uni., 143-152.

Amal M. El-Shraiy and Amira M. H. (2007). Impact of salicylic acid and paclobutrazol exogenous application on the growth, yield and nodule formation of common bean. Australian Journal of Basic and Applied Sciences, 1(4): 834840

Amal M. El-Shraiy and Amira, M. H. (2009). Effect of Acetylsalicylic Acid, Indole-3Butyric Acid and Gibberellic Acid on Plant Growth and Yield of Pea (Pisum Sativum L.). Australian J. Basic and Applied Sci., 3(4): 3514-3523.

Anita, G., Pramod, k., Bhatt, I. C., Dube, S. D. and Chauhan, V. S. (1999). Effect of environmental conditions, salicylic acid and phytohormones on pea leaf blight. Indian Phytopath, 52 (3): 270-273.

Azooz, M. M., Youssef, A. M. and Ahmad, P. (2011). Evaluation of salicylic acid application on growth, osmatic solutes and antioxidant enzyme activities on broad bean seedlings grown under diluted sea water. International journal of plant physiology and biochemistry, 3(14), pp. 253-264.

El-Hak, S. H. G., Ahmed, A. M. and Moustafa, Y. M. M. (2012). Effect of foliar application with two antioxidants and humic acid on growth, yield and yield components of peas (Pisum sativum L.). Journal of horticultural science \& ornamental plants, 4(3): 318328.

Mirvat, E. G., Hala, M. S. and Amany, A. R. (2005). Effect of antioxidants on growth, yield and favism causative agents in seeds of Vicia faba L. plants grown under reclaimed sandy soil. Journal of agronomy, 4(4): 281-287.

Nigam, A. K. and Gupta, V. K. (1979). Handbook on Analysis of Agricultural Experiments. $1^{\text {st }}$ edition, I.A.S.R.I. Publications, New Delhi.

Nour, K. A. M., Mansour, N. T. S. and Eisa, G. S. A. (2012). Effect of some antioxidants on some physiological and anatomical characters of snap bean plants under sandy soil conditions. New York Science Journal, 5(5):1- 9.

Tarchevsky, I. A., Yakovelva, V. G. and Egorova, A. M. (2011). Effect of salicylic acid on protein content and 14c amino acid incorporation into proteins of pea roots. Russian J. plant physiology, 58: 580-588.

Tomader, G. and Rahman, A. (2005). Effect of antioxidants on cowpea root rot disease. Annals Agric. Sci., 50(2), 589600 .

\section{How to cite this article:}

Thomson T., G. S. Patel, J. B. Thakar and Pandya K. S. 2017. Effect of foliar application of Acetyl Salicylic Acid and Ascorbic Acid on flowering, pickings and yield of garden pea (Pisum sativum L.) cv. Bonneville. Int.J.Curr.Microbiol.App.Sci. 6(6): 1977-1981. doi: https://doi.org/10.20546/ijcmas.2017.606.231 